\title{
THE CLOUD COMPUTING TECHNOLOGY FOR FUTURE DIGITAL TRANSPORT IN EUROPE
}

DATA PRZESŁANIA: 30.06.2016| DATA AKCEPTACJI: 5.07.2016|KOD JEL: 031

\section{Jolanta Joszczuk-Januszewska}

Gdynia Maritime University

Faculty of Navigation

e-mail: jolajj@am.gdynia.pl

ABSTRACT

KEYWORDS

The Internet and digital technologies are transforming our world - in every walk of life
and in every line of business. Europe must embrace the digital revolution and open up
digital opportunities for people and businesses. That is why the European Commission
has set the creation of a Digital Single Market (DSM) as one of its key priorities (May
2015). The DSM Strategy sets out three main pillars, where one of these is maximizing
the growth potential of European digital economy. This requires investment in Infor-
mation and Communications Technologies (ICT) such as Cloud Computing and Big
Data. Creating the DSM is a top priority for digitalization of transport. There are many
unseized opportunities resulting from the digitalization of the transport. This paper
aims to present the outline of support proposed by Big Data/Cloud platforms and new
opportunities which transport industry needs to achieve a digital transport market
in Europe.
digital transport, Cloud Computing and Big Data, Digital Single Market

\section{INTRODUCTION}

The global economy is rapidly becoming digital. Information and Communications Technology (ICT) is no longer a specific sector but the foundation of all modern innovative economic systems. The Internet and digital technologies are transforming the lives we lead, the way we work - as individuals, in business, and in our communities as they become more integrated across all sectors of our economy and society.

These changes are happening at a scale and speed that bring immense opportunities for innovation, growth and jobs. They also raise challenging policy issues for public authorities which 
require coordinated European Union (EU) action. All Member States are wrestling with similar problems but on a national basis which is too limited to allow them to seize all the opportunities and deal with all the challenges of this transformational change. For many issues the European level offers the right framework. That is why the European Commission (EC) has set the creation of a Digital Single Market (DSM) as one of its key priorities (SWD 100 final, 2015).

The DSM Strategy will be built on three pillars presented in this paper. One of these pillars is maximizing the growth potential of the digital economy. This requires investment in Information and Communications Technologies (ICT) such as Cloud Computing and Big Data, and research and innovation to boost industrial competiveness as well as better public services, inclusiveness and skills.

This Big Data phenomenon creates new possibilities to share knowledge, to carry out research and to develop and implement public policies. It is also becoming easier to exploit this data thanks to the Cloud (Assunçăo et al., 2015). The Cloud can be understood as the combination of three interdependent elements: the data infrastructures which store and manage data, the highbandwidth networks which transport data, and the ever more powerful computers which can be used to process the data.

Creating the DSM is a top priority for digitalization of transport. The EU has already initiated actions towards this direction. For example in maritime transport (Joszczuk-Januszewska, 2012, 2013). Nevertheless, there are many unseized opportunities resulting from the digitalization of the transport (Walker, 2015).

This paper aims to present the outline of support proposed by Big Data/cloud platforms and new opportunities which transport industry needs to achieve a digital transport market in Europe.

\section{INDUSTRY NEEDS TO ACHIEVE A DIGITAL TRANSPORT MARKET IN EUROPE}

We can distinguish four main supports (Draft Report, 2015):

1. Standards. Today, stakeholders use many different IT languages to exchange on transport and logistics processes. That compromises the quality and efficiency of the communication. There is therefore a need for technical systems to communicate in the same language across modes of transport in real time. The main problem about standards is not that there is a lack of standards, but that there are too many. Standards rely on the achievement of a harmonised implementation of procedures/rules. This involves the definition of the information owner, the availability of the information and which details/data are included in such information. All this aspects might diverge from a standard to another and lead to a lack of interoperability across systems, modes and countries.

2. Data reliability. An essential element in shipping and in other modes of transport is related to safety. Digitalisation of transport processes has the potential to improve reliability and certainty of information (i.e. about cargo transported), and thereby to positively impact on safety.

3. eDocuments. Progress is first needed to enable the use of electronic transport documents: in some countries, individual legislations at national level are a barrier to the use of electronic transport documents. Furthermore, the re-use of information already submitted can enable efficiency gains and cost savings. For example in the case of maritime transport, thanks to an eManifest, a ship upon entering the EU would provide the required information once, the same information being then re-used from port to port as needed. 
4. Big Data/Cloud platforms and new opportunities. A large quantity of data is generated in existing systems (big data, structured and unstructured). There is a high potential and an urgent need for exploiting those data more widely along the logistics chain, in combination with trust-building tools (data protection, cybersecurity, etc.), adequate data governance, business models (e.g. when sharing data or assets), transparency and integrity control. This can enable the provision of detailed shipment information to end-consumers, improve processes in real-time or enhance the predictability of transport operations.

\section{CLOUD COMPUTING IN DSM STRATEGY}

Cloud Computing is developing fast (RightScale, 2016). Recent estimates indicate that these developments could lead to the growth of the European cloud market (Cisco, 2015).

The development of the cloud computing market and the efficient delivery of cloud services particularly depend on the ability to build economies of scale. The establishment of a DSM will unlock the scale necessary for cloud computing to reach its full potential for digital transport in Europe.

On 6 May the European Commission (EC) unveiled its detailed plans to create a DSM which the Commission will deliver by the end of 2016 (COM 192 final, 2015). The DSM Strategy is built on three pillars (EC, 2015a, 2015b):

1. Better access for consumers and businesses to online goods and services across Europe; this requires the rapid removal of key differences between the online and offline worlds to break down barriers to cross-border online activity.

2. Creating the right conditions for digital networks and services to flourish - this requires high-speed, secure and trustworthy infrastructures and content services, supported by the right regulatory conditions for innovation, investment, fair competition and a level playing field.

3. Maximising the growth potential of digital economy - this requires investment in ICT infrastructures and technologies such as Cloud computing and Big Data, and research and innovation to boost industrial competiveness as well as better public services, inclusiveness and skills.

Creating the DSM is a top priority for transport and logistics in the EU (Draft Report, 2015). Within the DSM Strategy for Europe, cloud computing plays a key role. The European Commission (COM 176 final, 2016):

- launched on April 2016 European Cloud Initiative including cloud services certification, contracts, switching of cloud services providers and a research open science cloud,

- intends to support funding the development and use of the ICT standards needed to further improve the interoperability and portability of the cloud. This includes making more use of open source elements by better integrating open source communities into standards development organisations (SDOs') standard setting processes, by the end of 2016,

- will facilitate the adoption of cloud computing services by supporting the finalisation of international standards on service level agreements, by mid-2017. This will ensure transparency and quality for end users, especially SMEs,

- will request European standardisation organisations (ESOs) to update the mapping of cloud standards and guidelines for end users (especially SMEs and the public sector), in collaboration with international SDOs, cloud providers and end users, by mid-2017. 


\section{EUROPEAN CLOUD INITIATIVE - A BRIGHT OUTLOOK FOR CLOUD IN EUROPE}

European Cloud Initiative (ECI) helps create a DSM. On April 19, 2016 the Commission presented its blueprint for cloud-based services and world-class data infrastructure to ensure science, business and public services reap benefits of big data revolution (COM 178 final, 2016).

Europe is the largest producer of scientific data in the world, but insufficient and fragmented infrastructure means this 'big data' is not being exploited to its full potential. By bolstering and interconnecting existing research infrastructure, the Commission plans to create a new European Open Science Cloud that will offer Europe's 1.7 million researchers and 70 million science and technology professionals a virtual environment to store, share and re-use their data across disciplines and borders. This will be underpinned by the European Data Infrastructure, deploying the high bandwidth networks, large scale storage facilities and super-computer capacity necessary to effectively access and process large datasets stored in the cloud. This world-class infrastructure will ensure Europe participates in the global race for high performance computing in line with its economic and knowledge potential.

Focusing initially on the scientific community - in Europe and among its global partners the user base will over time be enlarged to the public sector and to industry. This initiative is part of a package of measures to strengthen Europe's position in data-driven innovation, to improve competitiveness and cohesion and to help create a DSM in Europe.

The ECI will make it easier for researchers and innovators to access and re-use data, and will reduce the cost of data storage and high-performance analysis. The Commission will progressively put in place the ECI through a series of actions, including (EC, 2016a):

a) as of 2016: creating a European Open Science Cloud for European researchers and their global scientific collaborators by integrating and consolidating e-infrastructure platforms, federating existing scientific clouds and research infrastructures, and supporting the development of cloud-based services;

b) 2017: opening up by default all scientific data produced by future projects under the $€ 77$ billion Horizon 2020 research and innovation programme, to ensure that the scientific community can re-use the enormous amount of data they generate;

c) 2018: launching a flagship-type initiative to accelerate the nascent development of quantum technology, which is the basis for the next generation of supercomputers;

d) by 2020: developing and deploying a large scale European high performance computing, data storage and network infrastructure, including by acquiring two prototype nextgeneration supercomputers of which one would rank among the top three in the world, establishing a European big data centre, and upgrading the backbone network for research and innovation.

In addition to the European research community, the European Open Science Cloud and the European Data Infrastructure will be accessible and bring benefits for a host of other users (EC, 2016a):

1. Businesses will have cost-effective and easy access to top level data and computing infrastructure, as well as a wealth of scientific data enabling data-driven innovation. This will particularly benefit SMEs, which typically lack access to such resources.

2. Industry will benefit from the creation of a large-scale cloud eco-system, supporting the development of new European technologies such as low-power chips for high performance computing.

3. Public services will benefit from reliable access to powerful computing resources and the creation of a platform to open their data and services, which can lead to cheaper, 
better and faster interconnected public services. Researchers will also benefit from online access to the wealth of data created by public services.

\section{THE CLOUD FIGURE IN EUROPE'S DATA LEGISLATION - EU-U.S. PRIVACY SHIELD}

According to one from top 10 cloud trends for 2016 the cloud will figure in Europe's data legislation (M.C. Today, 2016). The Court of Justice of the European Union (CJEU) recently invalidated the Safe Harbour Principles. This essentially means that any US company wanting to move user data across the Atlantic will need to declare their standards of data privacy. That's why major cloud providers are bound to get more interested in the subject 2016 year.

Most have already issued statements about their dedication to data privacy, but many still haven't developed a dedicated infrastructure in Europe. For them, 2016 will be an important year. They'll need to decide whether to continue their operation only in the US or commit to European data standards by taking part in the privacy debate.

On July 12, 2016 the EC adopted the EU-U.S. Privacy Shield. This new framework protects the fundamental rights of anyone in the EU whose personal data is transferred to the United States as well as bringing legal clarity for businesses relying on transatlantic data transfers (EC, 2016b). The EU-U.S. Privacy Shield is based on the following principles:

1. Strong obligations on companies handling data: under the new arrangement, the U.S. Department of Commerce will conduct regular updates and reviews of participating companies, to ensure that companies follow the rules they submitted themselves to. If companies do not comply in practice they face sanctions and removal from the list. The tightening of conditions for the onward transfers of data to third parties will guarantee the same level of protection in case of a transfer from a Privacy Shield company.

2. Clear safeguards and transparency obligations on U.S. government access: The US has given the EU assurance that the access of public authorities for law enforcement and national security is subject to clear limitations, safeguards and oversight mechanisms. Everyone in the EU will, also for the first time, benefit from redress mechanisms in this area. The U.S. has ruled out indiscriminate mass surveillance on personal data transferred to the US under the EU-U.S. Privacy Shield arrangement. The Office of the Director of National Intelligence further clarified that bulk collection of data could only be used under specific preconditions and needs to be as targeted and focused as possible. It details the safeguards in place for the use of data under such exceptional circumstances. The U.S. Secretary of State has established a redress possibility in the area of national intelligence for Europeans through an Ombudsperson mechanism within the Department of State.

3. Effective protection of individual rights: Any citizen who considers that their data has been misused under the Privacy Shield scheme will benefit from several accessible and affordable dispute resolution mechanisms. Ideally, the complaint will be resolved by the company itself; or free of charge Alternative Dispute Resolution (ADR) solutions will be offered. Individuals can also go to their national Data Protection Authorities, who will work with the Federal Trade Commission to ensure that complaints by EU citizens are investigated and resolved. If a case is not resolved by any of the other means, as a last resort there will be an arbitration mechanism. Redress possibility in the area of national security for EU citizens' will be handled by an Ombudsperson independent from the US intelligence services.

4. Annual joint review mechanism: the mechanism will monitor the functioning of the Privacy Shield, including the commitments and assurance as regards access to data 
for law enforcement and national security purposes. The EC and the U.S. Department of Commerce will conduct the review and associate national intelligence experts from the U.S. and European Data Protection Authorities. The Commission will draw on all other sources of information available and will issue a public report to the European Parliament and the Council.

Since presenting the draft Privacy Shield in February 2, 2016 the Commission has drawn on the opinions of the European data protection authorities (Art. 29 working party) and the European Data Protection Supervisor, and the resolution of the European Parliament to include a number of additional clarifications and improvements. The EC and the U.S. notably agreed on additional clarifications on bulk collection of data, strengthening the Ombudsperson mechanism, and more explicit obligations on companies as regards limits on retention and onward transfers.

The "adequacy decision" notified on July 12, 2016 to the Member States and thereby enter into force immediately. On the U.S. side, the Privacy Shield framework will be published in the Federal Register. The U.S. Department of Commerce will start operating the Privacy Shield. Once companies have had an opportunity to review the framework and update their compliance, companies will be able to certify with the Commerce Department starting August 1. In parallel, the Commission will publish a short guide for citizens explaining the available remedies in case an individual considers that his personal data has been used without taking into account the data protection rules.

On February 2, 2016 the EC and the U.S. Government reached a political agreement on a new framework for transatlantic exchanges of personal data for commercial purposes: the EU-U.S. Privacy Shield. The EU-U.S. Privacy Shield reflects the requirements set out by the European Court of Justice in its ruling on 6 October 2015, which declared the old Safe Harbour framework invalid.

\section{CONCLUSIONS}

Within less than a decade, most economic activity will depend on digital systems, integrating digital infrastructure, hardware and software, applications and data. Digitisation of all sectors will be needed if the EU is to maintain its competitiveness, keep a strong industrial base and manage the transition to a smart industrial and services economy. $75 \%$ of the value added by the digital economy comes from traditional industries, rather than ICT producers, but the integration of digital technology by businesses is the weakest element. Digitisation also offers unprecedented opportunities to other economic sector, such as transport (e.g. intelligent transport systems).

The EU needs a range of measures to ensure European industries are at the forefront of developing and exploiting ICT, automation, sustainable manufacturing and processing technologies to serve the markets of the future. A digital economy can also make society more inclusive. Citizens and businesses are not currently getting the full benefits from digital services (from e-government, e-health, e-energy to e-transport) that should be available seamlessly across the EU.

Cloud computing supports new digital services by providing the massive data storage and computational power needed for the digitisation of European industry and science. This is recognised in the Communication on the European Cloud Initiative which highlights the value of widening the user base of research and education networks. These networks are ideal for designing, specifying, testing and deploying standards. 
Proprietary solutions, purely national approaches and standards that limit interoperability can severely hamper the potential of the Digital Single Market. The take-up of cloud computing services by businesses, consumers, public administrations and the scientific sector requires seamless user-friendly access, but also trust and confidence, in particular regarding cloud providers' compliance with appropriate levels of data protection, security, and service levels. The Communication on the European Cloud Initiative highlights the need for the use of existing relevant certification and standards as well as - where appropriate - the creation of Europeanlevel certification and labelling.

Common open standards will help users access new innovative services, especially for SMEs, the public sector and the scientific community. In particular, the portability of applications and data between different providers is essential to avoid lock-in. This will require a mapping of cloud standards and guidelines for end users (especially SMEs and the public sector).

Establishing a sustained flow of information across modes of transport and countries thanks to interoperable systems and standards, with re-use of data and trustworthiness is deemed as essential in strengthening even further Europe's global competitive position.

On the subject of future digital transport in Europe the current strategy of Europe Commission is arrangements of Europe to reap the benefits of digital future, the online freedoms to profit fully from Europe's huge internal market, in particular. At present this strategy is a starting point only. The detailed scientific analysis of this problem will be presented later.

\section{REFERENCES}

Accompanying the document Communication from the Commission to the European Parliament, the Council, the European Economic and Social Committee and the Committee of the Regions (2015). A Digital Single Market Strategy for Europe. COM 192 final. Brussels.

Assunçăo, M.D. et al. (2015). Big Data computing and clouds: Trends and future directions. Journal of Parallel and Distributed Computing, 79-80, 3-15.

Cisco Inc. (2015). Cisco Global Cloud Index. Forecast and Methodology 2014-2019. Available at: www. ciscoknowledgenetwork.com/files/547_11-10-15-DocumentsCisco_GCI_Deck_2014-2019_for_ CKN__10NOV2015_.pdf?PRIORITY_CODE.

Commission Staff Working Document (2015). A Digital Single Market Strategy for Europe - Analysis and Evidence. SWD 100 final. Brussels.

Communication from the Commission to the European Parliament, the Council, the European Economic and Social Committee and the Committee of the Regions (2015). A Digital Single Market Strategy for Europe. COM 192 final. Brussels.

Communication from the Commission to the European Parliament, the Council, the European Economic and Social Committee and the Committee of the Regions (2016). ICT Standardisation Priorities for the Digital Single Market. COM 176 final. Brussels.

Communication from the Commission to the European Parliament, the Council, the European Economic and Social Committee and the Committee of the Regions (2016). European Cloud Initiative - Building a competitive data and knowledge economy in Europe. COM 178 final. Brussels.

Draft Report (2015). On the Digital Transport and Logistics Forum. 1st Plenary session Brussels, 1-2 July.

European Commission (2015a). A Digital Single Market for Europe: Commission sets out 16 initiatives to make it happen. Press release. Brussels, May 6.

European Commission (2015b). Digital Single Market Strategy: European Commission agrees areas for action. Press release. Brussels, March 25. 
European Commission (2016a). European Cloud Initiative to give Europe a global lead in the data-driven economy. Press release. Brussels, April 19.

European Commission (2016b). European Commission launches EU-U.S. Privacy Shield: stronger protection for transatlantic data flows. Press release. Brussels, July 12.

Joszczuk-Januszewska, J .(2013). Importance of Cloud-Based Maritime Fleet Management Software. In: J. Mikulski (ed.), Telematics in the Transport Environment. $12^{\text {th }}$ International Conference on Transport Systems Telematic, TST 2012. Katowice-Ustroń, 10-13 October (pp. 450-458). Berlin Heidelberg: Springer-Verlag.

Joszczuk-Januszewska, J. (2012). The Benefits of Cloud Computing in the Maritime Transport. In: J. Mikulski (ed.), Telematics in the Transport Environment. $12^{\text {th }}$ International Conference on Transport Systems Telematic, TST 2012. Katowice-Ustroń, 10-13 October (pp. 258-266). Berlin Heidelberg: Springer-Verlag.

M.C. Today (2016). Top 10 Cloud Trends for 2016. Available at: www.mobilecomputingtoday.co.uk/1880/10cloud-trends (22.07.2016).

RightScale (2016). State of the Cloud Report. Available at: www.rightscale.com/lp/2016-state-of-the-cloudreport.

Walker, J. (2015). Intelligent Transportation Systems. Report for Mobile. London: GSM Association.

\section{Technologia chmury obliczeniowej dla przyszłego cyfrowego transportu w Europie}

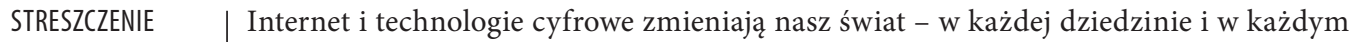
rodzaju działalności. Europa musi wkroczyć w epokę cyfrową i umożliwić wykorzystywanie możliwości świata cyfrowego zarówno obywatelom, jak i przedsiębiorcom. Dlatego Komisja Europejska (maj 2015) przedstawiła swoje szczegółowe plany dotyczące utworzenia jednolitego rynku cyfrowego (JRC), realizując tym samym jeden ze swoich najważniejszych celów. Strategia JRC będzie opierać się na trzech filarach, a jednym z nich jest maksymalizacja wzrostu gospodarczego generowanego przez europejską gospodarkę cyfrową. Wymaga to inwestycji w takie technologie, jak chmura obliczeniowa i duże zbiory danych. Tworzenie JRC jest najważniejszym priorytetem dla cyfryzacji transportu. Artykuł ma na celu przedstawienie zarysu wsparcia zaproponowanego przez dwie technologie - dużych zbiorów danych oraz chmury, a także nowych możliwości, jakie sektor transportu musi osiągnąć na rynku cyfrowego transportu w Europie.

SŁOWA KLUCZOWE $\quad$ transport cyfrowy, chmura obliczeniowa i „big data”, jednolity rynek cyfrowy

Tłumaczenie Jolanta Joszczuk-Januszewska 